\title{
Operational risk analysis with Fuzzy FMEA (Failure Mode and Effect Analysis) approach (Case study: Optimus Creative Bandung)
}

\author{
Taufiq Immawan*, Wahyudhi Sutrisno, and Annisa Kamilia Rachman \\ Universitas Islam Indonesia, 55584 DI Yogyakarta, Indonesia
}

\begin{abstract}
Industrial development in Indonesia, manufacturing and services, are required to be able to manage the company very well. However, in practice, the company's activities are always faced with risks. In general, the risk can be defined as a situation faced by a person or a company in which there is a possibility that harm. The level of risk faced losses due to highly variable depending on the cause and effect influence. To be able to manage (risk management), it can use FMEA (Failure Mode and Effect Analysis). FMEA is a method of analyzing potential failure are applied in product development, system engineering and operational management and is one of a qualitative risk assessment. Using FMEA can also note the value of the RPN (Risk Priority Number) to determine improvement priorities at risk. But there are weaknesses in the use of FMEA, namely RPN calculation is only done by multiplying the severity, occurence and detection alone and irrespective of the degree of importance of each input, to the FMEA method is integrated using fuzzy logic. Fuzzy FMEA is aimed at obtaining the highest fuzzyRPN value which will be used as the focus of improvements to minimize the possibility of these risks occur back. The results were obtained 7 out of 18 types of risks that have a high priority for repairs. Risk troublesome computer (hank / die) while doing photo editing scored the highest RPN 540 (scale 1-1000) and also the highest FRPN 9 (scale 1-10). There is a difference in value between RPN and FRPN. FRPN value obtained from the fuzzification, generate value by taking into account the degree of interest of any given input.
\end{abstract}

\section{Introduction}

The risk is related to uncertainty, this happens because of lack or unavailability of adequate information about what is going to happen. Something uncertain might be beneficial or detrimental to the company. According to Wideman (1992), which raises uncertainty the potential to benefit known as the chance (opportunity), while uncertainties which give rise to these adverse effects is called the risk. For the creation of good corporate governance cannot be separated from the application of risk management so that risk management is a vital force for good corporate governance. Risk management is very important so that it becomes an urgent matter that should be applied, because it is through the implementation of a formal risk management, structured and integrated company will be able to adapt to the business environment.

The main objective of risk management is to keep operational activities that do not cause losses which exceed the ability of business entities to absorb such losses or endangering its survival. One element of risk that will inevitably arise in the business life activity at a business entity is operational risk, and is also the oldest and the inherent risk that comes before other risks (Muslich, 2007). Basically operational risk management is the understanding that the operational risks faced by the company can be identified, measured, controlled, mitigated and reported correctly through the implementation of the risk management framework. Optimus Creative Company is one of the services in the field of graphic design, photography, yearbook and event organizer. In the process of operation, the company is always confronted with a variety of business operational risks derived from changes in external and internal environment relating to business management. Some of the business operating risks among which the delay in payment by the consumer, the delay in the printing process, errors in the editing photos, errors in the printing results, delays in delivery, complaints from consumers and others. In order to carry out its activities in order to minimize the potential occurrence of such risks, the company is in need of policies and guidelines for risk management so that goals and objectives can be achieved. The method used to overcome this problem is by applying Failure Mode and Effects Analysis (FMEA) and the use of fuzzy logic.

Failure Mode and Effects Analysis (FMEA) is one method of failure analysis / potential failure are applied in product development, system engineering and operational management and is one risk measurement / risk measurement category qualitative risk assessment

\footnotetext{
* Corresponding author: immawan16@gmail.com
} 
(Hanggraeni, 2010). Fuzzy logic is one method for analyzing systems that contain uncertainty (Kusumadewi S, 2002). The use of fuzzy logic in the FMEA to help determine the value of the Risk Priority Number (RPN) of failure occurring.

\section{Literature Review}

\subsection{Risk Definition}

Understanding the risks within the scope of the general public better known as something harmful from the presence of an incident. There are several definitions of risk, according to some experts, including:

- Risks in the Great Dictionary of Indonesian is a result of less favorable (adverse harm) of an acts.

- According Hanggraeni 2010 risk is an events that the potential to occur that might cause harm to a company.

- ISO / IEC Guide 73: 2002 Risk ManagementVocabulary-Guidelines for use in standards (2002) states that the risk is a combination of the probability of occurrence and consequences.

\subsection{Operational Risk}

Operational risk is the risk of most types of 'old' but least understood compared with other types of risks (eg market risk or interest rate). In this type of operational risk, there are inherent operational risk categories, namely risk arises because the company does business. For example, operational risk, namely, internal control systems are inadequate, work accidents, computer system failures, data corruption, failure to manage human resources (employees) and others. Basel II (which regulates international banking institutions) defines operational risk as the risk arising from the failure of internal processes, people, systems or from external events. There are two types of business operational risks that can be faced by the company (Hanggraeni, 2010), namely:

- The risk of non-entrepreneurial, that is a risk that was not caused by an entrepreneurial decision taken by the company. Companies usually use the services of insurance as a way to protect the company from this risk. Example: natural disasters, fires, and pollution.

- Entrepreneurial risk, namely the risk posed by the entrepreneurial decision taken by the company. If the company's business decisions and not precisely predict the decision, the company may experience significant losses. Example: the risk of build a new building, the risk of launching new products and the risk of merger.

\subsection{Risk Management}

Risk management is closely related to the company's sustainability. If the company carries out the management of risk, the company can avoid bankruptcy or even be able to generate increased profits. Risk management is a series of procedures and methodologies used to identify, measure, monitor and control risks arising from the business operations of a company (Hanggraeni, 2010). On the Project Risk Management PMBOK (2004), risk management is a systematic process of planning, identifying, analyzing, responding to and controlling risk.

Risk management is intended to ensure the sustainability of profitability and growth in line with the vision and mission of the company. In the control strategy and business risk management, corporate identification and risk maps (risk mapping), quantification and measurement of risk (risk measurement and assessment), risk management (risk treatment) as well as risk management policies (Hanggraeni, 2010). Risk Management process starting from identifying risk, analyzing risk, manage risk, risk management implementation and control of the application of risk management (ISO 31000-risk management system).

\subsection{FMEA (Failure Mode and Effect Analysis)}

Use of the method FMEA (Failure Mode and Effect Analysis) was first created in 1960 by the Aerospace Industry. In 1974, the Navy developed the so-called FMEA Procedure Mil-Std-1629 in which FMEA format is often used today. FMEA became popular after being used by the automotive industry to be implemented Integration into the product development process of their cars to overcome the problems of low product quality. FMEA until now still used primarily to prevent accidents and incidents at work (Mc Dermott, 2009).

Table 1. Severity rating scale

\begin{tabular}{|c|c|c|}
\hline Rating & Description & Criteria \\
\hline 10 & $\begin{array}{l}\text { Extremely } \\
\text { dangerous }\end{array}$ & $\begin{array}{l}\text { Failure could cause the death of a } \\
\text { customer (patient, visitor, } \\
\text { employee, staff member, business } \\
\text { partner) and/or total system } \\
\text { breakdown, without any prior } \\
\text { warning }\end{array}$ \\
\hline 9 & $\begin{array}{l}\text { Very } \\
\text { dangerous }\end{array}$ & $\begin{array}{l}\text { Failure could cause a major or } \\
\text { permanent injury and/or serious } \\
\text { system disruption with } \\
\text { interruption in service, with prior } \\
\text { warning. }\end{array}$ \\
\hline 7 & Dangerous & $\begin{array}{l}\text { Failure could cause a minor to } \\
\text { moderate injury with a high } \\
\text { degree of customer dissatisfaction } \\
\text { and/or major system problems } \\
\text { requiring major repairs or } \\
\text { significant re-work. }\end{array}$ \\
\hline 5 & $\begin{array}{l}\text { Moderate } \\
\text { danger }\end{array}$ & $\begin{array}{l}\text { Failure could cause a minor injury } \\
\text { with some customer } \\
\text { dissatisfaction and/or major } \\
\text { system problems. }\end{array}$ \\
\hline 4 & $\begin{array}{l}\text { Low } \\
\text { moderate } \\
\text { danger }\end{array}$ & $\begin{array}{l}\text { Failure could cause a very minor } \\
\text { or no injury but annoys customers } \\
\text { and/or results in minor system } \\
\text { problems that can be overcome } \\
\text { with minor modifications to the } \\
\text { system or process. }\end{array}$ \\
\hline 2 & Slight danger & $\begin{array}{l}\text { Failure could cause no injury and } \\
\text { the customer is unaware of the } \\
\text { problem; however, the potential } \\
\text { for minor injury exists. There is } \\
\text { little or no effect on the system. }\end{array}$ \\
\hline
\end{tabular}




\begin{tabular}{lll}
\hline Rating & Description & Criteria \\
\hline 1 & No danger & $\begin{array}{l}\text { Failure causes no injury and has } \\
\text { no impact on the system. }\end{array}$ \\
\hline
\end{tabular}

Source: Silva, M. M, 2014

FMEA is a structured procedure to identify and prevent as much as possible modes of failure. FMEA is used to identify the sources and root causes of quality problems. According to Wideman (1992), FMEA can be done by:

- Identify and evaluate the potential failure of a product and its effects.

- Registration process (document the process).

- Identify actions that could eliminate or reduce the chance of potential failure occurs.

In the use of FMEA methods have involved three things that assist in determining the risk to be able to know the value of the RPN (Mc Dermott, 2009), namely:

- Severity is the impact that arises when an error occurs. Table scale levels to the severity (damage) can be seen in Table 1.

- Occurrence is the likelihood or probability or frequency of occurrence of errors. Table scale levels for occurrence can be seen in Table 2 .

- Detection is possible to detect a fault will occur or before the impact of these errors occur. Table scale levels for detection can be seen in Table 3 .

Table 2. Occurence rating scale

\begin{tabular}{|c|c|c|}
\hline Rating & Description & Potential failure rate \\
\hline 10 & $\begin{array}{l}\text { Certain } \\
\text { probability of } \\
\text { occurence }\end{array}$ & $\begin{array}{l}\text { Failure occurs at least once a } \\
\text { day, or failure occurs almost } \\
\text { every time. }\end{array}$ \\
\hline 9 & $\begin{array}{l}\text { Failure is } \\
\text { almost } \\
\text { inevitable }\end{array}$ & $\begin{array}{l}\text { Failure occurs predictably, or } \\
\text { failure occurs every } 3-4 \text { days }\end{array}$ \\
\hline $\begin{array}{l}8 \\
7\end{array}$ & $\begin{array}{l}\text { Very high } \\
\text { probability of } \\
\text { occurence }\end{array}$ & $\begin{array}{l}\text { Failure occurs frequently, or } \\
\text { failure occurs about once per } \\
\text { week. }\end{array}$ \\
\hline $\begin{array}{l}6 \\
5\end{array}$ & $\begin{array}{l}\text { Moderately } \\
\text { high } \\
\text { probability of } \\
\text { occurence }\end{array}$ & $\begin{array}{l}\text { Failure occurs approximately } \\
\text { once per month. }\end{array}$ \\
\hline $\begin{array}{l}4 \\
3\end{array}$ & $\begin{array}{l}\text { Moderate } \\
\text { probability of } \\
\text { occurence }\end{array}$ & $\begin{array}{l}\text { Failure occurs occasionally, or } \\
\text { failure occurs once every } 3 \\
\text { months. }\end{array}$ \\
\hline 2 & $\begin{array}{l}\text { Low } \\
\text { probability of } \\
\text { occurence }\end{array}$ & $\begin{array}{l}\text { Failure occurs rarely, or failure } \\
\text { occurs about once per year. }\end{array}$ \\
\hline 1 & $\begin{array}{l}\text { Remote } \\
\text { probability of } \\
\text { occurence }\end{array}$ & $\begin{array}{l}\text { Failure almost never occurs; no } \\
\text { one remembers the last failure. }\end{array}$ \\
\hline
\end{tabular}

Source: Silva, M. M, 2014

Table 3. Detection rating scale

\begin{tabular}{lll}
\hline Rating & Detection & Definition \\
\hline 1 & $\begin{array}{l}\text { No chance of } \\
\text { detection }\end{array}$ & $\begin{array}{l}\text { There is no known mechanism } \\
\text { for detecting the failure. }\end{array}$ \\
\hline 2 & $\begin{array}{l}\text { Very } \\
\text { remote/unreli } \\
\text { able chance } \\
\text { of detection }\end{array}$ & $\begin{array}{l}\text { The failure can be detected only } \\
\text { with a thorough inspection, and } \\
\text { this is not feasible or cannot be } \\
\text { readily performed. }\end{array}$ \\
\hline
\end{tabular}

\begin{tabular}{lll}
\hline Rating & Detection & Definition \\
\hline 5 & $\begin{array}{l}\text { Remote } \\
\text { chance of } \\
\text { detection }\end{array}$ & $\begin{array}{l}\text { The error can be detected with a } \\
\text { manual inspection, but no process } \\
\text { is in place, so that detection left to } \\
\text { chance. }\end{array}$ \\
\hline 6 & $\begin{array}{l}\text { Moderate } \\
\text { chance of } \\
\text { detection }\end{array}$ & $\begin{array}{l}\text { There is a process for double- } \\
\text { checks or inspections, but it is not } \\
\text { automated and/or is applied only } \\
\text { to a sample and/or relies on } \\
\text { vigilance. }\end{array}$ \\
\hline 7 & $\begin{array}{l}\text { High chance } \\
\text { of detection }\end{array}$ & $\begin{array}{l}\text { There is 100\% inspection or } \\
\text { review of the process, but it is not } \\
\text { automated. }\end{array}$ \\
\hline 9 & $\begin{array}{l}\text { Very high } \\
\text { chance } \\
\text { detection }\end{array}$ & $\begin{array}{l}\text { There is 100\% inspection of the } \\
\text { process, and it is automated. }\end{array}$ \\
\hline 10 & $\begin{array}{l}\text { Almost } \\
\text { certain chance } \\
\text { of detection }\end{array}$ & $\begin{array}{l}\text { There are automatic "shut-offs" } \\
\text { or constraints that prevent failure. }\end{array}$ \\
\hline Source & Silva, M M 2014 &
\end{tabular}

Source: Silva, M. M, 2014

\subsection{Types of FMEA (Failure Mode and Effect Analysis)}

There are two types of FMEA according to Mc Dermott, Mikulak \& Beauregard (2009), namely:

1. Design / product FMEA.

Design / product FMEA is an analytical technique based on the design of engineering / team that includes a potential failure mode causes of mechanical failures that arise in the process. The systematic approach is taken in parallel, formal and all documents related to the design engineer through several processes. This design FMEA is used to analyze the product before input into the production process. Design FMEA focus on the mode of failure caused by the design.

2. Process FMEA.

Process FMEA is an analytical technique manufacturing or assembly process where in it contains a potential failure mode causes of mechanical failures that appeared in the production process. Each item of all the systems, sub-systems all the components should be evaluated. FMEA process is used to analyze the production and assembly process. FMEA of this type focused on the mode of failure caused by the production or assembly process.

\subsection{Procedure of FMEA (Failure Mode and Effect Analysis)}

There are ten steps in the procedure FMEA according to Mc Dermott, Mikulak \& Beauregard (2009). Even this procedure applies to all types of FMEA, good product / design and process. The ten steps are:

1. Review the process or product.

2. Conduct brainstorming failure mode (a potential failure mode).

3. Register effects of the failure of each failure mode.

4. Establish severity weights for each effect of failure.

5. Establish the weight of occurrence for each failure mode.

6. Establish the weight of detection for each failure mode/effect failure 
7. Calculate the value of the RPN (risk priority number) for each effect of failure. RPN is a measurement of the relative risk by multiplying the value of severity, occurence and detection. Within the scope of FMEA, this value can range from 1 to 1000. Mathematically it can be expressed as follows:

$\mathrm{RPN}=(\mathrm{S}) \times(\mathrm{O}) \times(\mathrm{D})$

In equation is the multiplication between the severity (S), occurence $(\mathrm{O})$ and detection (D). RPN is determined before setting a corrective action recommendations and used to prioritize action.

1. Prioritize failure modes that have the highest RPN.

2. Take measures to eliminate or reduce the failure modes that have the highest risk.

3. Recalculating the value of the RPN after the failure mode have been reduced or eliminated.

\subsection{Fuzzy Logic}

Fuzzy logic is a proper way to map an input space into an output space. There are several reasons why people use fuzzy logic, among others (Kusumadewi, 2002):

1. The concept of fuzzy logic is easy to understand. Mathematical concepts underlying the fuzzy reasoning is very simple and easy to understand.

2. Fuzzy logic is very flexible.

3. Fuzzy logic can tolerate data that is not appropriate.

4. Fuzzy logic is able to model non-linear functions are very complex.

5. Fuzzy logic can develop and apply the experiences of experts directly without having to go through the training process.

6. Fuzzy logic can work with techniques conventional control.

7. Fuzzy logic is based on natural language.

\subsection{Fuzzy FMEA (Failure Mode and Effect Analysis)}

Fuzzy logic is one method to analyze systems that contain uncertainty (Kusumadewi, 2002). Research using Fuzzy Logic will get more accurate results than using conventional FMEA. According to $\mathrm{Xu}$ et al. (2002) and Yeh \& Hsieh (2007), some weaknesses Conventional FMEA namely:

1. Statement of the FMEA often subjective and qualitative described in natural language.

2. Three levels of severity parameter $(\mathrm{S})$, occurance $(\mathrm{O})$ and detection (D) are assumed to have similar interests, it turns out in practice the weight of the interests of all three parameters are not the same.

3. The value of risk priority number (RPN) were produced by multiplying the level of S, O and D may imply a representation of risk.

To overcome the weakness - the weakness of the method is based on fuzzy logic is often used to manipulate the linguistic terms used directly in making a critical assessment. According to Iqbal et al. (2013), Fuzzy system is a knowledge-based system that is built on the expertise and experience in the form of fuzzy IF-THEN rules. Fuzzy inference method FMEA performed using
Mamdani or often known by the method of Max - Min introduced by Ebrahim Mamdani in 1975. To get a fuzzy output requires four steps:

1. Arrange the Fuzzy membership function.

2. Create a rule-based fuzzy logic.

3. Perform Fuzzy inference process.

\section{Case Study}

Optimus Creative was founded in 2010, located in Sarimanah, Bandung, West Java. Optimus Creative is a creative company advertising agency, Graphic Design, Photography, Videography and Event Organizer. Services offered by this company is more focused on the annual book production services (yearbook) for each of the schools in the city of Bandung. Optimus Creative has opened various branches in Yogyakarta, Jakarta, Tasikmalaya, so today has been a lot of work together in making the school yearbook with more than 100 school.

\subsection{FMEA Application}

In making the yearbook through six processes, namely the presentation, meeting concept, photo session, photo editing, printing and delivery. The entire process is not immune from the risks experienced. To be able to identify the overall risk and knowing the weights for each risk, then the distribution of questionnaires to all employees who work at the company's operations. The results of the questionnaire were as follows:

Table 4. Recapitulation questionnaire

\begin{tabular}{|c|c|c|c|}
\hline No & $\begin{array}{l}\text { Production } \\
\text { Process }\end{array}$ & Risk Identification & $\begin{array}{l}\text { Weighted } \\
\text { Average }\end{array}$ \\
\hline \multirow[t]{4}{*}{1.} & Presentation & $\begin{array}{l}\text { 1. Presentation materials } \\
\text { deleted/lost/not getting } \\
\text { carried away }\end{array}$ & 4 \\
\hline & & $\begin{array}{l}\text { 2. Facilities on site } \\
\text { presentations inadequate }\end{array}$ & 2 \\
\hline & & $\begin{array}{l}\text { 3. Team members did not } \\
\text { attend the presentation }\end{array}$ & 2 \\
\hline & & $\begin{array}{l}\text { 4. Termination of } \\
\text { unilateral presentation } \\
\text { by the client }\end{array}$ & 5 \\
\hline \multirow[t]{2}{*}{2.} & $\begin{array}{l}\text { Meeting } \\
\text { Concept }\end{array}$ & $\begin{array}{l}\text { 5. Disagreements bout the } \\
\text { concept of team and } \\
\text { client }\end{array}$ & 2 \\
\hline & & $\begin{array}{l}\text { 6. The objection about the } \\
\text { payment schedule }\end{array}$ & 4 \\
\hline \multirow[t]{6}{*}{3.} & $\begin{array}{l}\text { Photo } \\
\text { Session }\end{array}$ & $\begin{array}{l}\text { 7. Equipment for photo } \\
\text { session is damaged }\end{array}$ & 5 \\
\hline & & $\begin{array}{l}\text { 8. Bad weather when the } \\
\text { concept of photo out door }\end{array}$ & 2 \\
\hline & & $\begin{array}{l}\text { 9. Some students were } \\
\text { absent/late when the } \\
\text { photo session }\end{array}$ & 3 \\
\hline & & $\begin{array}{l}\text { 10. The late photographer } \\
\text { team attendance }\end{array}$ & 2 \\
\hline & & $\begin{array}{l}\text { 11. Errors photo location } \\
\text { information }\end{array}$ & 2 \\
\hline & & $\begin{array}{l}\text { 12. Unable to permit the } \\
\text { shooting lovation } \\
\text { (location not in a public } \\
\text { area) }\end{array}$ & 3 \\
\hline
\end{tabular}




\begin{tabular}{llll}
\hline 4. & Photo & $\begin{array}{l}\text { 13. Computer problems } \\
\text { Editing }\end{array}$ & 5 \\
& & $\begin{array}{l}\text { 14. File data is lost } \\
\text { 15. Misinformation } \\
\text { (different between the } \\
\text { photo and description) }\end{array}$ & 3 \\
& & $\begin{array}{l}\text { 16. The printer is trouble } \\
\text { 17. Result of the finishing } \\
\text { not appropriate }\end{array}$ & 5 \\
\hline 5. & Printing & & 5 \\
\hline
\end{tabular}

The results in Table 4 are then selected risks that have the highest average weight (score 5) for further processed using FMEA method. The main objective was to determine the method FMEA RPN value for each risk. RPN value is obtained by multiplying the value of severity, occurence and earlier detection that these values have been obtained through brainstorming and document review. RPN value can be seen in Table 5 .

Table 5. Calculation results of RPN

\begin{tabular}{|c|c|c|c|c|c|c|c|c|}
\hline $\begin{array}{l}\text { Potential } \\
\text { Failure }\end{array}$ & $\begin{array}{c}\text { Potential Effect(s) of } \\
\text { Failure }\end{array}$ & 空 & $\begin{array}{c}\text { Potential Cause(s) of } \\
\text { Failure }\end{array}$ & ¿ & $\begin{array}{c}\text { Current Process } \\
\text { Control }\end{array}$ & 昜 & Z̆ & ن் \\
\hline $\begin{array}{l}\text { Termination } \\
\text { of unilateral } \\
\text { presentation } \\
\text { by the client }\end{array}$ & $\begin{array}{l}\text { Presentation materials } \\
\text { conveyed not so big } \\
\text { possibility of } \\
\text { cooperation is not } \\
\text { established. }\end{array}$ & 6 & $\begin{array}{l}\text { Appearance and delivery of } \\
\text { material less attractive } \\
\text { presentation of the } \\
\text { company's presentation } \\
\text { team. }\end{array}$ & 2 & $\begin{array}{l}\text { Re-discuss with the } \\
\text { client to schedule a } \\
\text { presentation. }\end{array}$ & 8 & 96 & a1 \\
\hline $\begin{array}{l}\text { Equipment for } \\
\text { photo session } \\
\text { is damaged }\end{array}$ & $\begin{array}{l}\text { The scheduled } \\
\text { completion of the photo } \\
\text { session is too late, the } \\
\text { catch is less good } \\
\text { photos. }\end{array}$ & 5 & $\begin{array}{l}\text { Treatment of equipment } \\
\text { was not regularly }\end{array}$ & 4 & $\begin{array}{l}\text { Replacement of the } \\
\text { components of the } \\
\text { equipment have been } \\
\text { damaged when the } \\
\text { photo }\end{array}$ & 4 & 80 & $\mathrm{a} 2$ \\
\hline $\begin{array}{l}\text { Computer } \\
\text { problems } \\
\text { (hank on/off) }\end{array}$ & $\begin{array}{l}\text { Photo editing } \\
\text { workmanship exceeds } \\
\text { the specified deadline }\end{array}$ & 10 & $\begin{array}{l}\text { Treatment of the computer } \\
\text { is not on a regular basis, } \\
\text { companies do not have a } \\
\text { generator or a UPS } \\
\text { (Uninterruptible Power } \\
\text { Supply) to avoid the } \\
\text { computer suddenly died due } \\
\text { to power cuts. }\end{array}$ & 6 & $\begin{array}{l}\text { Repairs done when } \\
\text { knowing troubled } \\
\text { computer }\end{array}$ & 9 & 540 & a3 \\
\hline $\begin{array}{l}\text { File data is } \\
\text { lost }\end{array}$ & $\begin{array}{l}\text { Photo editing } \\
\text { workmanship exceeds } \\
\text { the specified deadline } \\
\text { and also can lead to the } \\
\text { repetition of the } \\
\text { previous process. }\end{array}$ & 10 & $\begin{array}{l}\text { The process data storage is } \\
\text { not good, data storage is } \\
\text { only performed in a data } \\
\text { storage medium }\end{array}$ & 2 & $\begin{array}{l}\text { Storage of data stored } \\
\text { on more than two data } \\
\text { storage media }\end{array}$ & 6 & 120 & $\mathrm{a} 4$ \\
\hline $\begin{array}{l}\text { The printer is } \\
\text { trouble }\end{array}$ & $\begin{array}{l}\text { Book page printout was } \\
\text { not optimal (there is a } \\
\text { shadow, the color is not } \\
\text { clear, etc.) and } \\
\text { workmanship mold } \\
\text { exceeds specified } \\
\text { deadline. }\end{array}$ & 9 & $\begin{array}{l}\text { Printing work overload and } \\
\text { lack of oversight and } \\
\text { periodic maintenance of the } \\
\text { printing press. }\end{array}$ & 7 & $\begin{array}{l}\text { The execution stops } \\
\text { after finding trouble } \\
\text { printing machine. }\end{array}$ & 6 & 378 & a5 \\
\hline $\begin{array}{l}\text { Result of the } \\
\text { finishing not } \\
\text { appropriate }\end{array}$ & $\begin{array}{l}\text { Poor final quality books } \\
\text { and pages in the book } \\
\text { are easily separated } \\
\text { from the book cover } \\
\text { stitching. }\end{array}$ & 7 & $\begin{array}{l}\text { Employees who work on } \\
\text { finishing the book lacks } \\
\text { focus and is not thorough. }\end{array}$ & 6 & $\begin{array}{l}\text { Conduct an } \\
\text { examination of the } \\
\text { results of the book } \\
\text { before the book } \\
\text { entered the process of } \\
\text { packaging and } \\
\text { shipping. }\end{array}$ & 8 & 336 & a6 \\
\hline $\begin{array}{l}\text { Delay in } \\
\text { delivery }\end{array}$ & $\begin{array}{l}\text { Causing complaints or } \\
\text { protests from the } \\
\text { students and the school. }\end{array}$ & 9 & $\begin{array}{l}\text { Work on editing and } \\
\text { printing is delayed, stalled } \\
\text { in the journey time of } \\
\text { delivery, fault location } \\
\text { information delivery. }\end{array}$ & 4 & $\begin{array}{l}\text { Confirm beforehand } \\
\text { with the school about } \\
\text { delays in the delivery } \\
\text { process }\end{array}$ & 9 & 324 & a7 \\
\hline
\end{tabular}




\subsection{Application of Fuzzy FMEA}

In the processing of fuzzy FMEA using conventional FMEA result, Matlab 8 is used as a tool pengoalahan data. Fuzzy Logic Matlab toolbox is a software program that has been used in calculating the values of Fuzzy RPN. A model that was built in the techniques of Fuzzy FMEA has 3 inputs (severity, occurence and detection) and 1 output variable (FuzzyRPN) (Kumru, 2012).

There are 5 levels of membership function in the input variables, ie Almost None, Low, Medium, High and Very High (Kumru, 2012). Of the five membership functions are then producing 125 fuzzy rules, which are used as a factor in determining the value fuzzyRPN. As for the variable output used 10 level membership function in output variables, namely None, Very Low, Low, High Low, Medium Low, Medium, High Medium, Low High, High and Very High (Kumru, 2012)

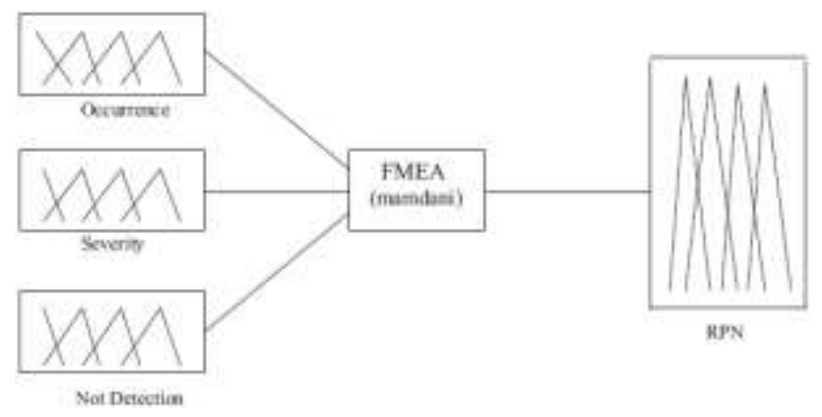

Fig 1. Fuzzy model

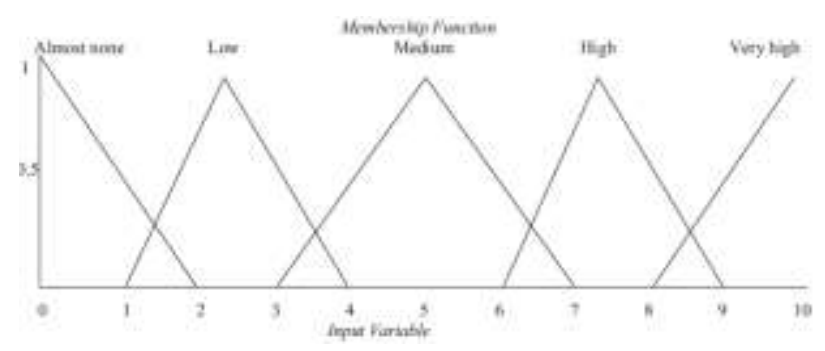

Fig 2. Input variable membership function

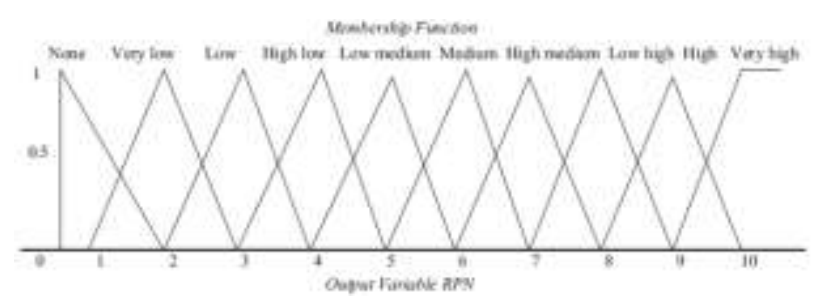

Fig 3. Output variable membership function

\subsection{Deffuzyfication}

Input from the process is the set Fuzzy defuzzyfication resulting from the process of composition and output is a value of One technique used in defuzzyfication is Center Of Gravity (Centroid). In Centroid, the output value is obtained based on the gravity of the decision-making process yield curve. In this study, defuzzification is used to find the value of output in the form of FRPN value of the input that has been entered. Inputs come from both the severity, occurence and detection that have been obtained from the results of FMEA risk identification using conventional methods (Table 5). Here are the results obtained from the FRPN defuzzification process using Matlab 8:

Table 6. Comparison of RPN and FRPN

\begin{tabular}{|l|c|c|c|c|c|c|c|}
\hline $\begin{array}{c}\text { Potential } \\
\text { Failure }\end{array}$ & S & O & D & RPN & $\begin{array}{c}\text { Priori } \\
\text { ty }\end{array}$ & FRPN & $\begin{array}{c}\text { Priori } \\
\text { ty }\end{array}$ \\
\hline $\begin{array}{l}\text { Computer } \\
\text { problems } \\
\text { (hank on/off) }\end{array}$ & 10 & 6 & 9 & 540 & 1 & 9 & 1 \\
\hline $\begin{array}{l}\text { The printer is } \\
\text { trouble }\end{array}$ & 9 & 7 & 6 & 378 & 2 & 8 & 3 \\
\hline $\begin{array}{l}\text { Result of the } \\
\text { finishing not } \\
\text { appropriate }\end{array}$ & 7 & 6 & 8 & 336 & 3 & 7 & 4 \\
\hline $\begin{array}{l}\text { Delay in } \\
\text { delivery }\end{array}$ & 9 & 4 & 9 & 324 & 4 & 9 & 2 \\
\hline $\begin{array}{l}\text { File data is } \\
\text { lost }\end{array}$ & 10 & 2 & 6 & 120 & 5 & 6 & 7 \\
\hline $\begin{array}{l}\text { Termination } \\
\text { of unilateral } \\
\text { presentation } \\
\text { by the client }\end{array}$ & 6 & 2 & 8 & 96 & 6 & 7 & 5 \\
\hline $\begin{array}{l}\text { Equipment } \\
\text { for photo } \\
\text { session is } \\
\text { damaged }\end{array}$ & 5 & 4 & 4 & 80 & 7 & 7 & 6 \\
\hline
\end{tabular}

Based on Table 6 there are the difference between the value and ranking among the NDP and FRPN. This is due to calculations using RPN simply done by multiplying the severity, occurence and detection alone and irrespective of the degree of importance of each input. While FRPN value obtained from the fuzzification, generate value by taking into account the degree of interest of any given input. In the process of defuzzification calculations have put the rules that prioritize the handling of the problem over to the cause of the risk. Whereas in the calculation of RPN, RPN value generated simply by multiplying the value of severity, occurence and detection only causing less accurate calculations with the NDP and the different results with calculations FRPN. Basically the method of fuzzy FMEA FMEA is more consistent than conventional methods.

\subsection{Risk Handling}

Here are some strategies for each risk than risk having the highest priority to low priority based on the calculation FRPN (Fuzzy Risk Priority Number):

1. Risk Priority 1: Computer problems (hang on / off) when editing pictures with a value FRPN 9

- Risk Mitigation

- Installation of double generator or UPS (Uninterruptible Power Supply) for all workstations

- Regular checks of the computer used (at least 1x1 month)

- Reset the computer's power cable installation on the layout of photo editing special work

2. Risk Priority 2: The delay in the delivery process with a value of RPN 9 
- Risk Mitigation

- Confirm the address with the recipient before sending

- Avoid delivery time during peak hours on the go

- Check the condition of the vehicle before transporting (avoid crashes vehicle)

3. Risk Priority 3: The print engine trouble during the process of printing the value FRPN 8

- Risk Mitigation Strategies

- The treatment is good against the printing press, especially after use

- Regular checks periodically for printing machines (minimum 1x1 month)

- Reset the printing schedule (avoid overload)

- Do not use a printing machine that has been aged $>10$ years

- Setting up a special printing machine technician

4. Risk Priority 4: Results of faulty finishing (disagree) with the value FRPN 7

- Risk Mitigation Strategies

- Application written SOP for the process of finishing a book

- Routine supervision of the workforce

- Procurement training for old and new workers

- Perform quality control before packaging

5. Risk Priority 5: Dismissal of unilateral presentation by the client (the school) with a value FRPN 7

- Risk Mitigation Strategies

- Prepare materials with interesting

- Election of members of attractive, physically attractive to the team presentation

- Using language that remained polite during the presentation

- Procurement training (public speaking) routine for the team presentation

6. Risk Priority 6: Equipment damaged when the photo photo session with the value FRPN 7

- Risk Mitigation Strategies

- Treatment of photo equipment properly and regularly

- Examination of photo equipment on a regular basis (at least $1 \mathrm{x} 1$ month)

- Storage equipment was stored in a place that is not wet or humid

- Avoid carry equipment that is not good (easy to fall)

7. Risk Priority 7: File photo editing data is lost with the value FRPN 6

- Risk Mitigation Strategies

- Preparation of a data base with the online system

- Implementation of additional applications of the data autosaved

- Storage of data is done in more than two data storage media (external hard drive, etc.)

- Implementation of data recovery application if at any time the data is lost / deleted

\subsection{Risk Control}

Controlling risk is done by organizing regular meetings periodically to evaluate the handling of such risks during this time. The formation of a team or a special division that handles risk management can also be done as a way of controlling risk. During the meeting, it can be evaluated the risks that usually happens, if there are new risks arising, eating could be immediately documented to be analyzed great danger and action to handle, and if there is a risk that is no longer relevant can also be eliminated. In addition, through regular meetings could be used to discuss current risk management strategies and continue to improve the strategy

\section{Conclusion}

Of the many known risks identified are 7 risks that have the highest weight for processing by the FMEA. The use of FMEA simply multiplying severity, occurence and detection alone to obtain the value of the RPN regardless of the degree the interests of each input. To cover the shortfall which is owned by the FMEA method is then integrated using fuzzy logic, then the difference of the results obtained with the conventional FMEA FuzzyFMEA. From the results obtained fuzzyRPN knowable risks becoming a priority for rapid repairs. The company can make the handling and controlling the risks that these risks do not occur in the future. One way is by applying risk mitigation actions for each risk and set up a special division that handles risk management.

\section{References}

1. Hanggraeni, D. Pengelolaan Risiko Usaha. Jakarta: Lembaga Penerbit Fakultas Ekonomi Universitas Indonesia (2010).

2. ISO/IEC Guide Risk Management-VocabularyGuidelines for use in standards (2002)

3. Iqbal, M., Muflikhah, L., \& Setiawan, N. Y.. Penggunaan Fuzzy Failure Mode and Effect Analysis (Fuzzy FMEA) dalam Mengidentifikasi Resiko Kegagalan Proses Pemasangan dan Perbaikan AC. Jurnal Informatika/Ilmu Komputer , 1-6. (2013)

4. Kumru, M. Fuzzy FMEA application to improve purchasing process in a public hospital. Turkey : Dept of Industrial Engineering, Dogus University (2012).

5. Kusumadewi, S. Analisis dan Desain Sistem Fuzzy Menggunakan Toolbox Matlab. Yogyakarta : Graha Ilmu (2002).

6. McDermott, R.E., Mikulak, J.E., Beauregard, M.R. The Basics of FMEA (2nd edition). New York : Productivity Press (2009).

7. Muslich, M. Manajemen Risiko Operasional, Edisi Pertama. PT Bumi Aksara (2007).

8. Project Management Institute (PMI). A guide to the project management body of knowledge (PMBOK®Guide). Pennsylvania: Project Management Institute (2004).

9. Silva, M,.M. A multi dimensional approach to information security risk management using FMEA and fuzzy theory. Brazil: International Journal of Information Management, Department of Production 
Engineering, Universidade Federal de Pernambuco (2014).

10. Wideman, M.R. Project and Program Risk Management: A Guide To Managing Project Risk Opportunities. Amerika Serikat: Project Management Institute (1992).

11. Xu, K., Tang, L. C., Xie, M., Ho, S. L., \& Zhu, M. L. Fuzzy Assessment of FMEA for Engine System. Reliability Engineering and System Safety, 17-29 (2002).

12. Yeh, R. H., \& Hsieh, M. H.. Fuzzy Assessment of FMEA for a Sewage Plant. Journal of the Chinese Institute of Industrial Engineers , 505-512 (2007) 